\title{
HUBUNGAN PERAN KELUARGA DENGAN KEPATUHAN MINUM OBAT PASIEN GANGGUAN JIWA DI KLINIK RAWAT JALAN RUMAH SAKIT JIWA DAERAH ABEPURA
}

\author{
Indrawaty Ismail ${ }^{1}$, Muh Rhomandoni ${ }^{2}$, Makmun Rosidy ${ }^{3}$ \\ ${ }^{1)}$ Mahasiswa Keperawatan STIKes Jayapura \\ ${ }^{2)}$ Rumah Sakit Jiwa Daerah Abepura \\ ${ }^{3)}$ Sekolah Menengah Atas Negeri 1 Sentani \\ email:watymarwan@gmail.com
}

\begin{abstract}
ABSTRAK
Latar belakang: gangguan jiwa di seluruh dunia sudah menjadi masalah yang sangat serius.Dalam penanganan terhadap pasien gangguan jiwa obat bukanlah segala-galanya, namun peran keluarga sangat diharapkan terhadap proses penyembuhan/ pengobatan pasien gangguan jiwa, karena semua pasien gangguan jiwa yang dalam perawatan harus berada di tengah keluarga. Peran keluarga yang perlu diperhatikan kepada pasien gangguan jiwa adalah kepatuhan minum obat. Tujuan: penelitian untuk mengetahui hubungan peran keluarga dengan kepatuhan minum obat pasien gangguan jiwa di klinik rawat jalan Rumah SakitJ iwa Daerah Abepura. Metode penelitian kuantitatif dengan studi cross sectional. Sampel: dalam penelitian ini sebanyak 37 keluarga pasien gangguan jiwa. Analisis data: menggunakana nalisis univariat dan analisis bivariat dengan ujichi-square.Hasil penelitian: diperoleh bahwa peran keluarga pasien gangguan jiwa di RSJD Abepura yang terbanyak mempunyai peran baik sebanyak 35 responden $(94,6 \%)$ dan kepatuhan minum obat pasien yang paling banyak adalah pasien patuh minum obat sebanyak 31 responden $(83,8 \%)$, hasil analisis menunjukkan diperoleh pvalue $=0,023$ atau $(p$ value $<0,05)$. Kesimpulan: ini berarti Ha diterima artinya ada hubungan antara peran keluarga dengan kepatuhan minum obat pasien gangguan jiwa RSJD Abepura.
\end{abstract}

Kata kunci: Kepatuhan Minum Obat, Pasien Gangguan Jiwa, Peran Keluarga

\section{ABSTRACT}

Backgrund of mental disorders around the world has become a very serious problem. In the treatment of patients with mental disorders medicine is not everything, but the role of the family is expected to the healing / treatment of patients with mental disorders, because all mental patients in care must be in the middle of the family. The family role that needs to be paid attention to mental disorder patients is medication adherence. The purpose of this research is to know the relation of family role with the adherence of medication to the patient of mental disorder in outpatient clinic of Abepura Regional Mental Hospital. Quantitative research method with cross sectional study.The sample in this study were 37 families of mental patients. Data analysis used univariateand bivariate analysis with chisquare test. The result of the research shows that the role of the family of mental disorder patients in Abepura Hospital has the most good role as 35 respondents (94,6\%) and the most patient medication adherence is the patient who has medication as much 31 respondent $(83,8 \%)$, analysis showed that $p$ value $=0,023$ or ( $p$ value $<0,05$ ). Conclusion: This means that $\mathrm{Ha}$ is accepted, meaning that there is a relationship between the role of the family and adherence to taking medicine for psychiatric patients in Abepura Regional Mental Hospital.

Keywords: Family role, Medication adherence, Mental disorders 


\section{PENDAHULUAN}

Era globalisasi adalah suatu era dimana tidak ada lagi pembatas antara negara di dunia khususnya di bidang informasi, ekonomi, dan politik.Perkembangan IPTEK yang begitu cepat dan perdagangan bebas yang merupakan ciri era ini, berdampak pada semua sektor termasuk sektor kesehatan termasuk kesehatan jiwa.

Sehat adalah keadaan sejahtera dari badan, jiwa, dan sosial yang memungkinkan setiap orang hidup produktif secara sosial dan ekonomi.Kesehatan mental adalah terhindarnya orang dari gejala-gejala gangguan jiwa (neurosa) dan dari gejalagejala penyakit jiwa (psikosa). Gangguan jiwa adalah kumpulan dari keadaan- keadaan yang tidak normal, baik yang berhubungan dengan fisik, maupun dengan mental. Keabnormalan tersebut dibagi ke dalam dua golongan yaitu: Gangguan jiwa (neurosa) dan sakit jiwa (Psikosa). Keabnormalan terlihat dalam berbagai macam gejala yang terpenting di antaranya adalah: ketegangan (tension), rasa putus asa dan murung, gelisah, cemas, perbuatan- perbuatan yang terpaksa (convulsive), hysteria, rasa lemah, dan tidak mampu mencapai tujuan, takut, pikiran-pikiran buruk dan sebagainya. (Yosep,2010).

Menurut data World Health Organization (WHO), masalah gangguan jiwa di seluruh dunia memang sudah menjadi masalah yang sangat serius.WHO menyatakan, paling tidak, ada satu dari empat orang di dunia yang mengalami gangguan kesehatan jiwa.Sementara itu menurut Direktur WHO Wilayah Asia Tenggara, hampir satu per tiga dari penduduk pernah mengalami gangguan neuropsikiatri. Data Survei Kesehatan Rumah Tangga (SKRT) tahun 1995, di Indonesia diperkirakan sebanyak 264 dari 1000 anggota rumah tangga menderita gangguan kesehatan jiwa.

Hasil penelitian yang mendukung dari Pratiwi (2011:06) bahwa RSJ Prof. Dr.HB Saanin Padang menerima jumlah pasien skizofrenia yang berobat setiap bulan Januari - Juni tahun 2010 mencapai 300 pasien.

Dalam penanganan terhadap pasien gangguan jiwa obat bukanlah segalagalanya, namun peran keluarga sangat diharapkan terhadap proses penyembuhan/pengobatan pasien gangguan jiwa. Kondisi ini menyebabkan pentingnya peranan keluarga, karena keluarga merupakan kelompok terkecil yang dapat berinteraksi dengan pasien. Secara pribadi, keluarga merupakan faktor utama dalam proses penyembuhan pasien (Fitrishia, 2008).

Peran keluarga pada pasien gangguan jiwa yaitu memberikan perhatian yang lebih, karena semua pasien gangguan jiwa yang dalam perawatan harus berada di tengah keluarga, masalah yang ada yaitu minimnya fasilitas kesehatan mental sehingga penanganan pasien tidak optimal dan penanganan oleh keluarga lebih mudah. Dengan beban dan penderitaan keluarga serta ketidaktahuan mereka menghadapi gejala yang timbul akan melahirkan sikap dan emosi yang keliru dan berdampak negatif pada pasien, sehingga memicu kekambuhan (Sukawati, 2009). Peran keluarga disini dibutuhkan untuk mewujudkan proses penyembuhan pasien dimana keluarga dapat memberikan bantuan berupa bantuan emosional/ perhatian, informasi/ pengetahuan (kognitif), dan material/ sosial ekonomi, yang sering disebut sebagai peran keluarga (Ambar, 2010).

Kepatuhan adalah istilah yang digunakan untuk menggambarkan perilaku pasien yang patuh obat, yang menyelasaikan pengobatannya teratur dan lengkap tanpa terputus selama pengobatan (Robert, 2010). Kepatuhan terhadap minum obat merupakan masalah utama dalam kekambuhan. Adapun faktor-faktor yang mempengaruhi kepatuhan dalam minum obat yaitu kurang pahamnya pasien tentang tujuan pengobatan tidak mengertinya tentang pentingnya mengikuti aturan pengobatan yang ditetapkan sehubungan dengan prognosisnya.sukarnya memperoleh obat di luar rumah sakit, mahalnya harga obat, dan kurangnya perhatian dan peran keluarga dalam pemberian obat itu kepada pasien (Tambayong, 2012).

Data awal yang dilakukan di klinik rawat jalan Rumah Sakit Jiwa Daerah 
Abepura jumlah pasien gangguan jiwa yang menjalani rawat jalan berulang di poliklinik pada bulan Juli-Desembar tahun 2017 sebanyak 3.026 pasien. Dari hasil wawancara yang dilakukan kepada 5 orang anggota keluarga pasien yang menjalani rawat jalan berulang menyatakan bahwa keluarga tidak mengetahui bagaimana cara perawatan pasien di rumah seperti kepatuhan minum obat, pasien sering mengalami putus obat karena susah untuk minum obat sehingga obat yang diberikan oleh dokter tidak habis sesuai tanggal untuk kembali kontrol.

Berdasarkan masalah di atas, maka peneliti tertarik untuk melakukan penelitian dengan judul, "Hubungan Peran Keluarga Dengan Kepatuhan Minum Obat pasien gangguan jiwa di Klinik Rawat Jalan Rumah Sakit Jiwa Daerah Abepura".

\section{METODE PENELITIAN}

Penelitian ini adalah penelitian kuantitatif dengan menggunakan pendekatan studi cross sectional, dimana peneliti melakukan pengukuran terhadap variabel bebas (peran keluarga) dan variabel terikat (kepatuhan minum obat pasien gangguan jiwa) pada subjek penelitian sebanyak satu kali penelitian kuisioner dalam waktu yang sama (Sugiyono, 2010). Penelitian dilakukan di klinik rawat jalan RSJD Abepura pada tanggal 21 sampai 28 Mei 2018 sebanyak 37 responden.

\section{HASIL PENELITIAN}

\section{Analisis Univariat}

Dalam penyajian analisis univariat dibuat menggunakan tabel diantaranya meliputi karakteristik responden seperti:usia, jenis kelamin, tingkat pendidikan dan pekerjaan.

Tabel 1 Karakteristik

\begin{tabular}{cc} 
responden & \\
\hline Karakteristik & $\begin{array}{c}\text { Frekuens } \\
\mathrm{i}\end{array}$
\end{tabular}

\begin{tabular}{lcc}
\hline Usia & & \\
15-24 tahun & 5 & 13,5 \\
25-40 tahun & 18 & 48,6 \\
Total & 37 & 100,0 \\
\hline Jenis Kelamin & & \\
Laki-laki & 14 & 37,8 \\
Perempuan & 23 & 62,2 \\
Total & 37 & 100,0 \\
\hline Tingkat Pendidikan & & \\
SD & 7 & 18,9 \\
SMP/Sederajat & 6 & 16,2 \\
SMA/Sederajat & 12 & 32,4 \\
D3/S1 & 12 & 32,4 \\
Total & 37 & 100,0 \\
\hline Pekerjaan & & \\
PNS & 5 & 13,5 \\
Wiraswasta & 10 & 27,0 \\
Lain-lain & 22 & 59,5 \\
Total & 37 & 100,0 \\
\hline Bela
\end{tabular}

Berdasarkan karakteristik

responden menurut usia, dari 37 responden diketahui sebagian besar berusia antara 25-40 tahun sebanyak 10 orang atau $48.6 \%$,berusia 40 tahun keatas sebanyak 14 orang atau $37.8 \%$.

Berdasarkan karakteristik responden menurut jenis kelamin dari 37 responden, diketahui sebagian besar berjenis kelamin perempuan sebanyak 23 orang atau $62.2 \%$ dan berjenis kelamin laki-laki sebanyak 14 orang atau 37,8\%.

Berdasarkan karakteristik responden menurut tingkat pendidikan, diketahui sebagian besar responden memiliki tingkat pendidikan SMA/sederajat dan D3/S! sebanyak 12 orang atau $32,4 \%$, SD sebanyak 7 orang atau $18,9 \%$ dan terendah SMP/sederajat sebanyak 6 orang atau 16,2\%.

Berdasarkan karakteristik responden menurut jenis pekerjaan, dari 37 responden yang memilii pekerjaan sebagian besar lain- lain sebanyak 22 orang atau $59,5 \%$, wiraswasta 10 orang atau 27,0 dan terendah dengan jenis pekerjaan sebagai PNS sebanyak 5 orang atau $13,5 \%$.

Tabel 2 Peran Keluarga

\begin{tabular}{|c|c|c|}
\hline Peran Keluarga & $\begin{array}{c}\text { Frekuens } \\
\mathrm{i}\end{array}$ & $(\%)$ \\
\hline Kurang & 2 & 5.4 \\
\hline Baik & 35 & 94.6 \\
\hline Total & 37 & 100.0 \\
\hline
\end{tabular}


Pada tabel di atas berdasarkan peran keluarga, menunjukkan bahwa peran keluarga di poliklinik RSJD Abepura sebagian besar memiliki peran keluarga baik sebanyak 35 orang atau $93,6 \%$ dan terendah memiliki peran keluarga kurang sebanyak 2 orang atau $5,4 \%$.

Tabel 3 Perilaku Kepatuhan Minum Obat

\begin{tabular}{lcc}
$\begin{array}{c}\text { Perilak } \\
\mathrm{u}\end{array}$ & $\begin{array}{c}\text { Frekuens } \\
\mathrm{i}\end{array}$ & $(\%)$ \\
\hline $\begin{array}{l}\text { Tida } \\
\mathrm{k}\end{array}$ & 6 & 16.2 \\
$\begin{array}{l}\text { Patu } \\
\mathrm{h}\end{array}$ & & \\
Patuh & 31 & 83.8 \\
\hline Total & 37 & 100.0 \\
\hline
\end{tabular}

Pada tabel di atas menunjukan bahwa perilaku kepatuhan minum obat pasien gangguan jiwa di poliklinik RSJD Abepura sebagian besar patuh sebanyak 31 orang atau $83,8 \%$ dan tidak patuh sebanyak 6 orang atau $16,2 \%$.

\section{Analisis bivariat}

Uji Chi Square digunakan untuk mengetahui hubungan peran keluarga dengan Perilaku Kepatuhan Minum Obat Pasien Gangguan Jiwa di Poliklinik RSJD Abepura dapat dilihat pada tabel di bawah ini:

Tabel 4 Hubungan peran keluarga dengan kepatuhan minum obat pasien

\begin{tabular}{|c|c|c|}
\hline & $\begin{array}{l}\text { Peran } \\
\text { Keluar } \\
\text { ga }\end{array}$ & $\begin{array}{l}\text { Kepatuhan Minum } \\
\text { Obat } \\
\text { Pasien Gangguan } \\
\text { Jiwa }\end{array}$ \\
\hline Chi-Square & $29.432^{\mathrm{a}}$ & $\begin{array}{c}16.8 \\
92^{\mathrm{a}}\end{array}$ \\
\hline Df & 1 & 1 \\
\hline $\begin{array}{l}\text { Asymp. } \\
\text { Sig. }\end{array}$ & .000 & .000 \\
\hline
\end{tabular}

Tabel hasil penelitian ini menunjukkan bahwa terdapat hubungan yang bermakna antara peran keluarga dengan perilaku kepatuhan minum obat pasien gangguan jiwa di Poliklinik RSJD Abepura dengan nilai probabilitas atau asymp. Sig 0.000 .

\section{PEMBAHASAN}

\section{Peran Keluarga}

Hasil penelitian menunjukan bahwa peran keluarga di poliklinik RSJD Abepura sebagian besar dikatakan baik sebanyak 35 orang $(94,6 \%)$ dan kurang sebanyak 2 orang $(5,4 \%)$. Hal ini ditunjukan dengan sebagian keluarga mengetahui tentang peran keluarga dengan kepatuhan minum obat pasien gangguan jiwa yang meliputi perhatian, pengetahuan dan social ekonomi (Ngastiyah, 2015).

Pengetahuan berkaitan erat dengan pendidikan seseorang. Hal ini sesuai dengan pendapat Muhazam (2014) yang menyatakan bahwa pendidikan formal pada dasarnya akan memberikan kemampuan Kepada seseorang untuk berfikir rasional dan objektif dalam menghadapi masalah hidup dan akan berdampak timbulnya suatu proses pengembangan atau pematangan pandangan hidup pribadi. Semakin tinggi tingkat pendidikan seseorang diharapkan di ikuti oleh semakin tingginya tingkat pengetahuan seseorang.

Senada dengan hal diatas hasil penelitian menunjukan bahwa mayoritas responden mempunyai pendidikan yang tinggi (SMA, D3 / S1) dimana pengetahuan dan pemahaman responden tentang pengobatan pasien gangguan jiwa lebih baik dibandingkan yang berpendidikan rendah.

Peran keluarga merupakan bagian dari dukungan sosial yang berfungsi sebagai sistem pendukung anggota-anggotanya dan ditujukan untuk meningkatkan kesehatan dalam proses adaptasi (Gohlieb, 2013).

Keluarga merupakan sistem pendukung utama yang memberikan perawatan langsung pada pasien 
gangguan jiwa. Peran keluarga dibedakan menjadi tiga dimensi peran emosional, dimensi informasional dan dimensi peran material (Keliat, 2011).

\section{Perilaku Kepatuhan Minum Obat}

Hasil penelitian menunjukan bahwa perilaku kepatuhan minum obat pasien gangguan jiwa di poliklinik RSJD Abepura sebagian besar patuh sebanyak 31 orang $(83,8 \%)$ dan tidak patuh sebanyak 6 orang $(16,2 \%)$. Hal ini menunjukan bahwa sabagian besar pasien patuh dalam mengkonsumsi obatobatannya baik secara mandiri karena pasien tersebut telah memahami tentang obat-obatan yang dikonsumsinya maupun karena masih dipantau oleh keluarganya.

Hasil penelitian ini bertolak belakang dengan teori Siregar (2015) yang mengatakan bahwa pada umumnya semakin banyak jenis dan jumlah obat yang digunakan pasien, semakin tinggi resiko ketidakpatuhan pasien dimana pemberian obat pada jangka waktu yang sering membuat ketidakpatuhan dan berbagai studi menunjukan bahwa ketidakpatuhan menjadi lebih besar, apabila periode pengobatan lama karena ketaatan pada pengobatan jangka panjang lebih sulit dicapai. hal senada juga dikatakan pleh Kaplan dan Sadok, 2009 yang mengatakan kompleksitas penggunaan obat (jumlah maupun dosis) merupakan faktor resiko ketidakpatuhan, pasien yang mendapatkan tiga jenis medikasi dalam satu hari atau jika medikasinya harus digunakan lebih dari empat kali dalam sehari cenderung tidak patuh terhadap pengobatannya.

Kepatuhan (compliance) juga dikenal sebagai ketaatan (adherence) adalah derajat dimana pasien mengikuti anjuran klinis dari dokter yang mengobatinya. Kepatuhan dalam pengobatan (medication compliance) adalah mengkonsumsi obat-obatan yang diresepkan dokter pada waktu dan dosis yang tepat dan pengobatan hanya efektif apabila anda mematuhi peraturan dalam menggunan obat (Maharani,2013).

Sebanyak $16,2 \%$ pasien kurang patuh terhadap pengobatannya. Hal ini dikarenakan berdasarkan wawancara yang dilakukan terhadap keluarga pasien bahwa pasien tidak patuh dalam pengobatan karena pasien bosan menelan obat setiap hari dan tidak suka rasa obat dank arena lama rawat pasien yang cukup lama. Hal ini sesuai dengan pendapat siregar (2012) bahwa masalah kepatuhan berkaitan dengan rasa obat-obatan dimana sejumlah pasien menghentikan penggunaan obat karena alasan rasa dan ketidakpatuhan menjadi lebih besar apabila periode pengobatan lama.

\section{Hubungan Peran Keluarga Dengan Tingkat Kepatuhan Minum Obat Pasien Gangguan Jiwa}

Hasil penelitian menunjukan bahwa terdapat hubungan yang bermakna antara peran keluarga dengan perilaku kepatuhan minum obat pasien gangguan jiwa di Poloklinik RSJD Abepura dengan nilai probabilitas atau asymp. Sig. 0.000. Hasil penelitian ini sesuai dengan hasil penelitian yang dilakukan oleh Yulishati (2015), hasil penelitian hubungan peran keluarga dengan tingkat kepatuhan minum obat di peroleh nilai $\mathrm{p}=0.000$ sehingga dapat disimpulkan terdapat hubungan yang signifikan antara peran keluarga dengan tingkat kepatuhan minum obat. Dengan taraf signifikasi sebesar $99 \%$.

Hal ini berarti adanya hubungan yang adil dan mereka yang memberikan perawatan kesehatan, dimana kedua pihak tersebut dapat menegosiasikan dan 
mengungkapkan kebutuhankebutuhan dan kepentingan mereka secara terbuka (Friedman, 2010).

\section{KESIMPULAN}

Berdasarkan hasil analisis dalam penelitian ini, maka dapat disimpulkan:

1. Hasil penelitian menunjukan bahwa peran keluarga di poliklinik RSJD Abepura sebagian besar dikatakan baik sebanyak 35 orang $(94,6 \%)$ dan kurang sebanyak 2 orang $(5,4 \%)$.

2. Hasil penelitian menunjukan bahwa perilaku kepatuhan minum obat pasien gangguan jiwa di poliklinik RSJD Abepura sebagian besar patuh sebanyak 31 orang $(83,8 \%)$ dan tidak patuh sebanyak 6 orang $(16,2 \%)$.

3. Adanya hubungan peran keluarga terhadap kepatuhan minum obat pasien gangguan jiwa di klinik rawat jalan Rumah Sakit Jiwa Daerah Abepura. Hasil uji statistik dengan menggunakan chi square menunjukkan diperoleh nilai $\mathrm{p}$ value $=0,000$ atau $(\mathrm{p}$ value $<0,05)$.

\section{DAFTAR PUSTAKA}

\section{Fitrishia, F. 2008. Peranan Keluarga dalam Proses Pengobatan Pasien Gangguan Jiwa dengan Studi Kasus: Keluarga yang anggotanya Dirawat di RSJ. Prof. H.B. Sa'anin Padang. Universitas Andalas: Padang.}

Friedman, (2010).Keperawatan Keluarga Teori dan Praktek. Edisi 3. EGC. Jakarta..

Kaplan H.I, Sadock B.J, Grebb J.A. (2010). Sinopsis Psikiatri jilid 2. Terjemahan Widjaja Kusuma. Jakarta: Binarupa Aksara. P. 17-35.

Pratiwi, (2011), Faktor-faktor yang berhubungan dengan kepatuhan minum obat pada pasien skizofrenia di poliklinik RSJ Prof. Dr. HB
Saanin Padang.

Robert, 2010.A grounded theory of fsmiliesresponding to mentalillness. Western Journal of Nursingesearch, 24 CJ,516-536. Siregar, S. 2015. Metode penelitian kuantitatif. Jakarta: prenamedia Group

Sugiyono, 2010. Metode penelitian administrasi, Bandung: CV. Alfabeta.

Sukawati, 2009.Psikologi untuk keperawatan,Jakarta: EGC.

Tambayong, 2012.Buku Saku Psikiatri. Jakarta: EGC. Yosep. 2010.Keperawatan Jiwa.Bandung: RefikaAditama.

Yulishati. 2015. Hubungan peran keluarga dengan tingkat kepatuhan minum obat pasien.

Diakses tanggal 20 Juli 2018. 